\title{
SOME REMINISCENCES OF AN IOWA SOLDIER.
}

BY COL. GEORGE W. CROSLEY.

It was my great privilege to have enjoyed an intimate personal acquaintance with the late Charles Aldrich, founder of The Historical Department of Iowa. He was a frequent and welcome guest at my home in Webster City. I had often-in response to his urgent request-related to him events of which I was either a witness or in which I was a participant, during my experience as a soldier from 1861 to 1865 . He had as often urged me to write out these reminiscences for publication in the Annals of Iowa. I had partially complied with his request by preparing a paper on "Lauman's Charge at Jackson," which was published in Volume 1, of the Annals. Since his death $I$ have regretted that $I$ had not been more responsive to his wishes in this regard. Now that I have passed the seventy-third mile-stone on my journey of life, and am reminded that the fiftieth anniversary of the battle of Shiloh is very near at hand, and recalling, as I do, the deep interest with which Mr. Aldrich listened to my description of the scenes and incidents of that and other battles in which I had taken part, I am impelled to offer for publication in the Annals some further recollections of those old war days.

The memories of a soldier, whose service extended over four years of active duty in the field, include so many events of greater or less interest and importance that it would require a volume of hundreds of pages in which to describe them. It is my purpose in this article to touch upon only a few of those events, and thus not exceed a reasonable limitation of space. I shall, therefore, recall only the experiences which relate to two of the numerous occasions in which my regiment engaged in battle with the enemy, and give an account of some of the incidents which have left the most vivid impression upon my memory. In the article heretofore published in the Annals, 
I have described the desperate charge made by my regiment and brigade on the 12th day of July, 1863. In that charge we suffered the greatest loss-in proportion to the number engaged-which was met by my regiment in any of its battles, although upon that occasion we were under the fire of the enemy for a shorter time than in any of the others.

My personal service embraced a wide experience in different capacities, extending from that of First Sergeant of Company E, Third Regiment Iowa Volunteer Infantry to First Lieutenant, Major, Brevet Lieutenant Colonel, and Colonel of that regiment, and-near the close of the war-I received the appointment of Major in Hancock's Veteran Army Corps. After my first promotion, I was at various times in command of my regiment, and thus had actual experience in most of the phases of a soldier's life, except that of being taken prisoner, which direful misfortune I was happy in escaping.

In the summer and fall of 1861, my regiment was in active service in the State of Missouri. We had numerous skirmishes with the enemy and had several men killed and wounded during the summer, but our heaviest loss had been from sickness resulting from the hardships and exposure to which we had been subjected. On the 17th day of September, 1861, at Blue Mills Landing, on the Missouri river, we had our first experience in battle. Lieutenant Colonel John Scott was in command of our regiment. We had marched from Cameron, on the Hannibal and St. Jo Railroad, to Liberty, Mo., within four miles of Blue Mills Landing, and halted there to await the arrival of reinforcements before proceeding to attack the enemy, who were reported to be in large force at the Landing. We had waited several hours for Colonel Smith, of the Sixteenth Illinois Infantry, who was reported to be near at hand with his regiment and other troops, and were becoming impatient on account of the fact that it was getting late in the afternoon, and we feared that the enemy-who had a steamboat and a couple of barges at their command-would retreat across the river before our forces could unite and join in the attack. While holding a conference with his officers, Lieutenant Colonel Scott received information that the rebels had been advised of the approach of 
our reinforcements, and that they had already commenced to cross the river. 'We then decided to move forward, after sending a courier to Colonel Smith, advising him of the situation and urging him to hasten his march. It was presumed that that portion of the enemy's force which had crossed the river would, upon hearing of our advance, return. That, however, would take time, and most likely enable Colonel Smith to arrive, either in time to participate in the engagement at its commencement, or at least to reinforce us during its progress. We had with us a company of cavalry, which we had used for scouting purposes, and which was sent forward to locate the enemy's position. In attempting to accomplish that purposein which they were only partially successful-the company met with a severe loss in killed and wounded. Among the killed were the Captain of the company and four of his men, who fell near each other. My company-of which I was then First Lieutenant-saw those dead men lying near the road, and were thus reminded of the fate that surely awaited some of us, for we knew that the enemy was in close proximity and that we must soon become engaged in deadly conflict.

- I have often been asked to describe the sensation I experienced upon first going into battle. I can only say that, while not indifferent to the danger that confronted us, $I$ was eager for the fighting to begin and to have my courage put to the test. Upon comparing notes with my comrades-after the battle was over-I found that the sensations experienced were about the same with all of us." Our skirmishers were soon hotly engaged and, in' a few minutes, the conflict became general. We had advanced through thick timber and inderbrush, which gave concealment to the enemy, and therefore enabled them to withhold their fire until we were close upon them. While it was very evident that the enemy not only had the advantage of position, but that their force was greatly superior to our own in point of numbers; we did not abandon hope that we would be able to hold our ground until reinforcements should arrive. We continued to fight desperately for over an hour. We saw our comrades being killed and wounded; but our personal danger was not to be considered. At length our 
brave commander realized that-in order to avoid being surrounded-it was necessary for us to retreat, and the order was given. Immediately the thought came to us-should we be able to extricate ourselves from the danger of capture which now threatened us? Everything depended upon the manner in which the retreat, under fire, was to be conducted. It was of supreme importance that the coolness, courage and skill of the officers should be conspicuously exhibited, in order to prevent the thing most to be dreaded in battle-a panic. Although this was their first experience in a real battle, and, notwithstanding the adverse conditions under which it was fought, the men showed no evidence of panic, but behaved with the same fortitude and courage which distinguished them in all the battles in which they were subsequently engaged.

The retreat was successfully conducted, and, just as night was closing in, the enemy-having been constantly held in check by a galling fire from our rear guard-abandoned the pursuit. Shortly after this our reinforcements arrived, but night had fallen and it was not deemed wise to renew the conflict before morning. During the night, however, the enemy had crossed the river and were beyond our reach.

In this battle we had made the mistake of attacking a largely superior force of the enemy, under the supposition-believed to be well-founded-that the troops marching to our assistance were within supporting distance. Had they been able to reach us in time, there is not a reasonable doubt that we would have won a substantial victory. Greater mistakes were madewith more disastrous results - on many occasions during the war, by both Union and Confederate commanders of high rank. In the dreadful trade of war, as well as in the peaceful avocations of life, experience is often purchased at heavy cost.

Mingled with the tragedies of battle there sometimes occurs an incident of grave humor, which, while it may not at the time occasion an out-break of boisterous mirth, is subsequently recalled with that effect. During the battle of Blue Mills, Major William M. Stone was wounded in the head, while gallantly discharging his duty. His friend, Captain Daniel P. Long, of Company B, who was near the Major when he fell and 
was bending over his unconscious form, had located the wound and supposed it was fatal. In a few moments, however, the Major began to regain consciousness and-rising to a sitting posture-shouted in stentorian tones, which rose above the din of battle: "Mr. Sheriff, adjourn the court!" To appreciate the humor of this command, it must be remembered that at the commencement of the war Major Stone was one of the Judges of the District Court of the State of Iowa. During the session of his court, in Washington, Iowa, on that memorable day when the news of the firing upon Fort Sumter was flashed over the wires, Judge Stone had just ordered a new jury impaneled, when some one handed the sheriff a telegram, which he at once passed to the Judge. Upon reading the telegram Judge Stone immediately gave the order: "Mr. Sheriff, adjourn the Court sine die!" and added "I am going home to raise a Company for the war." In the interval of being restored to a conscious condition, the Major's mind had evidently reverted to the commotion in the court room which followed his order to the sheriff instead of the commotion of battle then going on about him. After his recovery from his wound he was often reminded by his brother officers of his order to adjourn the court at Blue Mills, and as often replied: "Well, it was a proper order considering the circumstances surrounding the Court at the time it was given." Major Stone was subsequently made Colonel of the Twenty-second Iowa Infantry and achieved distinction while in command of that regiment. He afterwards served two terms as Governor of Iowa.

Among the particularly sad incidents of the battle of Blue Mills was the death of Thomas M. Mix, son of Quartermaster Sergeant Edward H. Mix. At the commencement of the war, father and son had enlisted on the same day and enjoyed each other's comradeship until that fatal day when the son gave his life for his country. His father-although greatly depressed by his bereavement-was all the more determined to go forward in the discharge of his duty. He was subsequently commissioned Lieutenant Colonel of the Thirty-second Iowa Infantry, and was killed in battle at Pleasant Hill, La., April 9, 1864. He was a brave and capable officer, and one of 
the most self-sacrificing and patriotic men I ever knew. It is a satisfaction to recall the pleasant hours I spent in companionship. with him. He was one of nature's noblemen-the kind of man whose friendship is both a privilege and an honor.

Lieutenant Colonel Scott, who commanded in the battle of Blue Mills, had been the Captain of the company in which I enlisted. He was a veteran of the Mexican War, a true soldier, and a man of superior ability. Every man and officer in the regiment bore witness to his conspicuous coolness and courage under the hottest fire of the enemy. He was a large man and was mounted upon an iron grey horse proportionate in size and was, therefore, more exposed to danger than any other officer. It seemed impossible that he should escape death; but he was not even wounded. His hat and clothes were several times. pierced with balls, and it seemed miraculous to his comrades that his life was spared. His horse was struck several times, but not so seriously injured as to prevent him from carrying his rider through the battle. Lieutenant Colonel Scott was afterward made Colonel of the Thirty-second Iowa Infantry, and won glory and honor for himself and his regiment in the hard-fought battle of Pleasant Hill, La. He was a true patriot, resigning a seat in the Senate of Iowa, and leaving wife and children and a pleasant home to enter the service of his country. After the close of the war he was twice elected a member of the State Senate, and was also its President while serving as Lieutenant-Governor of Iowa.

Major John F. Lacey was one of the brave and gallant soldiers who fought in the ranks at Blue Mills. He was then Fourth Corporal of Company H, Third Iowa Infantry. He afterwards became a First Lieutenant in the Thirty-third Iowa Infantry, was promoted to the rank of Major, and served with distinction on the staff of Major General Frederick Steele. Since the close of the war Major Lacey has rendered distinguished public service as Representative in Congress from the Sixth Congressional District of Iowa, serving in that capacity for eight terms. He has also won distinction as one of the ablest lawyers in the State. 
Seymour D. Thompson, First Sergeant of Company F, Third Iowa Infantry, was another one of the gallant fighters at Blue Mills. He was near the writer of these lines during the greater part of the engagement, and I can bear testimiony to the fact that, among all the brave men who took part in that battle, none did more to inspire his comrades, by his example of coolness and courage; than Sergeant Thompson: He subsequently won well deserved promotion to the rank of Captain in the Third United States Heavy Artillery', in which capacity he served until the close of the war. In civil life he won fame and distinction as an attorney, jurist, and eminent law-writer.

Having planned a visit to some friends in other Iowa regiments encamped at Pittsburg Landing, on the morning of April 6, 1862, I rose very early-nearly an hour before the time for reveille-and betook myself to a little stream some distance from our eamp, for the purpose of taking a bath. On the way I was beguiled by the morning songs of the birds and the fragrance of the wild flowers, and sauntered slowly along until I came to the little pool where I had been in the habit of bathing: Just then I heard the sound of reveille and knew I must hasten in order to get back to camp by the time breakfast would be ready. I was just in the act of taking off the last garment, preparatory to stepping into the water, when -boom-boom-boom-boom! came the sound of cannon away to the front. I listened intently for a few moments and could detect the sound of musketry intermingled with the louder reports of artillery, and became convinced that a severe conffict was in progress at the extreme front of our lines, about two miles from the place where I was standing.

I concluded that was no time to take a bath, hurried into my clothes, and started on a swift run for camp. Before I had accomplished half the distance, I heard the long roll beating in all the camps and knew that a great battle must be impending. With all the speed of which I was capable I ran towards our camp and, when I came in sight of it, saw my regiment formed on the color line. Rushing to my tent I grasped my belt and, buckling it around me as I ran, took my place in line at the head of my company. I knew that many of my things were 
scattered about my tent, but that was no time to look after them. Later I found that my trunk had been saved by the Quartermaster, but all my property that was not in it became the spoils of the rebels when they captured our camp that evening. I had not breakfasted, but I was entirely oblivious of that fact. We stood there in line for some little time before the order came to advance, and I might have gone to the mess tent and procured some food, but the thought did not occur to me. I found that most of my comrades had been equally improvident, and those of us who survived the battle went nearly without food for the two days of its duration. On the morning of the second day a comrade gave me a hard cracker and a piece of Bologna sausage, and that was all the food I tasted from Saturday night until Monday night.

Before the order came to move to the front, the officers were engaged in talking to their men, reminding them of the instructions they had received with regard to keeping cool and steady under fire, of paying strict attention to orders, that the duty of looking after the wounded belonged to the surgeons and stretcher bearers, and that while the fighting was going on it was the sole duty of each soldier to inflict as much damage upon the enemy as possible, that no soldier should think for a moment of retreating until he received orders to do so, that any exhibition of cowardice would meet with condign punishment. The men were all duly impressed by these admonitions. In the two days' battle that ensued, there were of course some instances in which-in response to the dictates of humanityboth officers and men temporarily turned aside to succor. a wounded comrade and prevent his falling into the hands of the enemý, but such acts were not regarded as a serious intention to disobey orders. In so far as my observation extended, but one instance of actual cowardice occurred in my own regiment, and in that case, I am glad to say, the soldier afterwards fully redeemed himself. As we advanced to meet the enemy we met many stragglers from the front, whose regiments were falling back before the severe fire which they had encountered. Some of these men were wounded; others, who were not injured, had become panic-stricken. A few of the latter regained 
courage at the sight of fresh troops coming into action and, joining our ranks, again marched against the enemy, but most of them seemed utterly demoralized and continued their mad flight to the rear.

We soon encountered the enemy in strong force. My regiment and brigade went into action with a ringing cheer, and in a short time drove the rebels from our immediate front and across an open field of about ten acres to the shelter of the woods beyond. Several batteries of artillery-both from the Union and Rebel lines-now engaged in a fierce conflict, while the infantry on both sides waited in breathless expectation for the order to advance, while exposed to the exploding shells and whistling grape-shot, and suffering numerous casualties. The heaviest loss came later on, when the deadly musketry fire was delivered at close range, the enemy charging across the open field with such courage and gallantry as challenged our admiration.

We had-for the second time-repulsed as desperate a charge as was made upon any part of that battlefield. It was now about half past three o'clock on Sunday afternoon. There was a lull in the conflict while both sides were preparing for a renewal of the deadly struggle. The enemy's dead were thickly strewn over the field in our front, while our own lay upon all sides a bout us. In some places they were intermingled, so close had been the opposing lines to each other. We replenished our ammunition-which had become nearly exhaustedand quietly awaited the advance of the enemy. On the opposite side of the field we could see the rebel officers riding to and fro along their lines, evidently encouraging their men to make a last desperate effort to break our lines. To our left heavy firing was still going on, and we kept looking anxiously in that direction to see whether our troops there engaged would be able to keep the enemy in check, and thus prevent them from outflanking and compelling us to abandon the position we had so far been able to maintain against them.

Suddenly the din of the conflict on our left increased to a steady roar, mingled with the victorious yells of the enemy. It at once became evident that our troops on the left were 
giving ground, and that the enemy had succeeded in turning their flank and would soon be able to render our position untenable. Just at this moment the enemy again appeared in our front. They came at a charging step, their officers waving their swords, and the familiar rebel yell rising above the roar of our batteries, which were dealing death and destruction in their ranks. We withheld our musketry fire until they were close upon us, and then delivered it with terrible effect. They began to waver and fall back, but, at that critical moment, we found ourselves exposed to a flanking fire from the left, and nothing remained for us but to abandon our position in order to avoid being surrounded. This we did in good order, but with heavy loss from the concentrated fire in our front and on our left. During this severe struggle several notable instances of personal bravery came under my immediate observation. I can close my eyes and recall those scenes of carnage as distinctly as though it were but yesterday instead of fifty years ago.

Sergeant Jacob Swank, of Company F, had been shot through the calf of the right leg during the second charge, and had also received a slight scalp wound, the blood from which covered his face as he stooped to bandage the wound in his leg with his handkerchief_-using a stick as a tourniquet to stop the flow of blood. I asked him if the ball had struck the bone, and he replied, "No, I can walk all right." As he looked up to answer my question, his face presented a bloody spectacle, but he laughed and said: "That wound in my head is not so bad as it looks, it is only a scratch." I ordered him to go to the rear and have his wounds attended to by the surgeon, but he begged to be allowed to stay with his comrades. Just then the charge was renewed, and, when the retreat began, there was Sergeant Swank, ably assisting me in keeping his company in line, coolly loading and firing his musket, and remaining on duty until the close of the battle.

When the regiment was compelled to retreat, it kept well in line. The men would deliver their fire, then about face and move rapidly to the rear, loading as they went; then, at the word of command, turn and fire and retreat again. In this 
manner we succeeded in checking the advance of the enemy until we had reached and passed through our own camp ground, within the limits of which many officers and men were killed or wounded. Here fell two of the best and bravest men of my own company-John M. Skiff and James H. Ewing. We afterwards found them lying close to each other. They had been very intimate friends and it seemed fitting that they should have fought and died together. The death of these men made an unusually deep impression on the minds of their surviving comrades, because of the fact that they both had a strong presentiment that in the battle-that all were expecting would soon be fought-they would be killed. Singular as it may seem, all those in my company who were killed at Shiloh had been impressed with the same feeling, as was afterwards recalled by one or more of their comrades. Others, however, who survived may have had the same presentiment, which they did not reveal. For myself, while never ignoring the probability of such a fate, I can truthfully say that I both hoped and expected that my life would be spared.

Just as we had reached the farther edge of our camp ground the enemy. was closing in on both flanks. Looking to the right and left we could see them rapidly narrowing the gap in our rear, which constituted our only chance of escaping capture. Up to this time we had kept facing to the rear and firing, thus keeping the enemy in check; our retreat was thus retarded, and we now found ourselves almost surrounded. The alternative left for us was to run the gauntlet or surrender. We did not hesitate for a moment, but dashed forward towards the open space in our rear, leaving only our dead and wounded in the hands of the enemy. When that gap closed behind us there was nothing left for such of our troops as had failed to retreat. in time but to surrender.

In and near our camp ground the rebels reaped a rich harvest of prisoners, including the survivors of the Eighth, Twelfth and Fourteenth Regiments of Iowa Infantry. Among those of the Third Iowa who fell into the hands of the enemy was the gallant Major Stone, whose horse was shot under 
him during the retreat. He was caught under the horse and, before he could extricate himself, was taken prisoner.

At a later period in the war, after Major Stone had been re. leased from imprisonment and had become Colonel of the Twenty-second Iowa, his regiment was encamped in our vicinity. I-in company with a number of my brother officerscalled upon him at his headquarters. He was very glad to see us and we were soon engaged in recalling the eventful scenes through which we had passed at Shiloh. Some one remarked that he had been told that Major Stone had said he was laboring under the impression, at the time he was captured, that the entire regiment had shared his fate. He promptly replied: "That is true, gentlemen, and you must admit that I was not far wrong in holding that opinion, for-as a matter of fact-I did surrender the "Major' portion of the regiment."

Just after we had passed our camp ground the brave Captain M. M. Trumbull-later Colonel of the Ninth Iowa Cavalry, and Brevet Brigadier General-was wounded, and fell immediately in front of me. I stopped and raised him to $a^{\prime}$ sitting posture, but he insisted upon my leaving him, saying it was better for him to be captured than for me to share his fate. Just then Joseph MeGinnis-a large and powerful soldier of Captain Trumbull's company (I)-came to the rescue, shouldered his Captain and bore him to a place of safety in the rear. Shortly after this we rallied and reformed our line and-in company with other troops-held the enemy in check near the point of last resistance, where Colonel Webster, of General Grant's staff, had massed a number of batteries, which opened upon the advancing rebel troops just as night was closing in. It was there that the tide of battle turned in our favor, and the day was saved for the Union Army.

As an instance of signal bravery I recall the return of Joseph McGinnis to his company, after he had carried his Captain off the field. When he had gone to the rear all seemed lost, and, in returning, he had expected to either die with his comrades or be captured with them. No more noble act of heroism was performed on that field. Before closing my reminiscences of the first day of the battle I want to recall two or 
three notable incidents. Soon after our retreat began, and the men had reloaded their guns, I had given the order to halt, about face, and fire. The enemy was following us closely and must have suffered severely from the volley we gave them at close range, as the cartridges for our muskets contained an ounce ball and three buckshot. Sergeant Thomas Mulvana, of my company, had just fired his musket, when he was shot through the heart and fell dead. Private John L. Woods-a close friend and comrade of Mulvana-seized hold of the body and was making an effort to carry it off the field, when he was shot and fell across the dead body of his friend. We found them in that position after the close of the battle. The presumption was that Woods thought Mulvana was not dead, but only unconscious from a severe wound, and that he resolved to rescue him from falling into the hands of the enemy. Be that as it may, Woods sealed his devoted friendship by the sacrifice of his life.

Several times during the retreat, which was marked by a trail of blood, the enemy came within easy pistol range and I -in common with those of my brother officers who had escaped death or wounds-discharged our revolvers in the faces of our foes, reloaded and emptied them again and again. First Lieutenant John P. Knight of Company I-afterwards Lieutenant Colonel of the Ninth Iowa Cavalry-had just emptied his revolver and was in the act of reloading it when he was struck in the left forearm and also in the right leg. He detached his sword and scabbard from his belt, and, using it as a cane, hobbled along for a short time as best he could. I saw him just as we reached our camp ground and then lost sight of him. He afterwards told me that he stumbled and fell and, before he could get upon his feet, the enemy were upon him and he was compelled to surrender.

Our Quartermaster, George W. Clark-afterwards Colonel of the Thirty-fourth Iowa Infantry and later a Brigadier General-was a brave man. The duties of his office kept him out of battle, but while he had remained in camp, looking after the regimental transportation and supplies, knowing that his regiment was in the thick of the fight, he became so anxious 
that he could no longer restrain the impulse to ride to the front and see how things were going with us. He reached the regiment just after we had repulsed the second charge of the enemy and while there was a lull in the firing in our immediate front. He was sitting on his horse, talking with a group of officers- of which I was one-when Major Stone rode up and ordered him to return to his place in the rear, saying to him: "Those of us who survive will need your valuable services when this fight is over and we don't want you to get killed." Just then the enemy's batteries again opened from the opposite side of the field, and Quartermaster Clark reluctantly left us and rode away to the rear. He afterwards told me that he rode slowly until he was well out of sight of the regiment, and then rode rapidly back to camp. Not long after we began our retreat the shells from the enemy's guns were falling about our camp, and Quartermaster Clark at once set about loading up the supplies and sending them to the rear. He succeeded in saving the knapsacks of the men and most of the officers' baggage. I still have the old trunk he saved for me and some of the relics it contained; I also have the old sword and belt, and the brace of revolvers I carried and used at Shiloh. These grim reminders of the old war days are highly prized by my family.

During the retreat my regiment had become separated from the other regiments of the brigade and had been fighting its own battle until we reached the point I have mentioned, where the first day's conflict ended. Our casualties had been very heavy. We had lost one hundred and eighty-seven in killed, wounded and captured. Nearly all of those who were captured -thirty men and officers-were wounded; our total loss was a little over one-third of the number engaged. Our loss in officers was very heavy. Of the twenty-six commissioned officers who had reported for duty in the morning, only seven were left for duty in the evening, none of them above the rank of Lieutenant. After the fall of Captain Trumbull, I was the senior in rank of those who remained and, therefore, the command of the regiment devolved upon me. I reported to Colonel M. M. Crocker of the Thirteenth Iowa Infantry, and was assigned by him to a position on the right of his regiment. There we remained 
during the tremendous artillery duel which ensued and continued until darkness put an end to the first day's battle. We then rejoined our brigade and lay upon our arms during the night.

I will not here attempt to give an account of the events connected with the second day of the battle of Shiloh. Suffice it to say that the Third Iowa Infantry contributed its full share in achieving the glorious victory won by the Union Army before the close of that day. We returned to our camp just as the shades of night were falling, almost completely exhausted. No detail was made upon our regiment that night for picket duty, because of the fact that none of us were able to perform that service, and there was little need of it, for the entire rebel army was in full retreat towards Corinth, Miss. Some rations had been procured for us, but the tired men-even in their almost famished condition-were content to partake of only coffee and hard crackers before lying down and lapsing into profound slumber. I had lain down as soon as I had given the order to stack arms on the color line and break ranks, and had gone to sleep almost as soon as I touched the ground. I was soon awakened by two of my good comrades, who invited me to partake of the coffee, bacon and hard crackers they had prepared and were anxious to share, with me. Hungry as I was, I would have preferred to have slept without breaking my fast until morning, but, not wishing to show lack of appreciation of the kindness of those men, I thankfully accepted their invitation, and never did food taste better than that we ate by the smoldering camp fire that night. After satisfying the cravings of hunger, we were soon sleeping soundly under the open sky. So deep and profound was our slumber that we did not awaken until the sun had arisen.

Our camp presented a scene of wreck and desolation. The tents were rent and torn almost to fragments, showing how fiercely the storm of battle had raged there. The dead-both friends and foes-lay all around us. Our first duty was to gather up our dead comrades, both there and on other parts of the field where they had fallen. We buried them with the honors of war, near our camp. This sad duty performed, we 
furnished details, to join those from other commands in burying the dead of the enemy, which duty was not wholly completed until two days after the close of the battle. While our own dead were buried in separate graves, it was impossible to perform a like office for all those of the enemy. They were mostly buried in long trenches, the rapid decomposition of the bodies rendering this a necessity, and making it a most disagreeable duty. Let it not be imagined, however, that we were lacking in respect for the rebel dead. We admired the valor with which they had met death, and recognized the fact that they fell fighting for a cause they believed to be just. Like our dead comrades, they had been animated with patriotic devotion to the flag under which they fought, and had sealed that devotion with their lives. While we cherished no resentment against these men who had fallen, we rejoiced in the victory we had won, and were firmly resolved to go forward in the discharge of our duty to our flag and country, until the final victory was achieved and a lasting peace restored.

The dear woman who became my wife on the 16th day of: April, 1864, (when I wás on veteran furlough with those of my comrades who had re-enlisted to serve during the remainder of the war,) has preserved the letters which I wrote her during all the years of my soldier life. Among those letters is a long one written a few days after the battle of Shiloh. That letterwritten while everything which I had observed was fresh in my mind-describes some of the incidents I have depicted in this article. In those days, while I was in the full vigor and strength of young manhood, I was inclined, perhaps, to somewhat extravagant expressions, but, after again reading that letter, written fifty years ago, I am inclined to the opinion that it is better than anything I have written since. Had my dear wife given her permission, I might well have offered that old letter-even with all its words of love and endearment-in place of much that is contained in this article. My wife accompanied me to the Shiloh Battlefield some years ago, to witness the dedication of the beautiful Iowa monuments erected there. 
After the dedication, we went to the old Third Iowa camp ground, and I pointed out to her the location of my tent and the place where I sat when I wrote her that letter. We also went over the ground where my regiment had fought, and followed the line of retreat back to the old camp ground, and on to the line of last resistance on Sunday night, and there I showed her where my regiment formed for the last determined and successful stand against the enemy. There stands the marker showing our position, near where the splendid Iowa State Monument now stands. Needless to say the occasion was to both of us one of deep and lasting significance.

But few of the old regiment remain upon earth at the time these lines are written, and they are widely separated, I being the only survivor living in Hamilton County. But two of my old company are living in Story County, where it was organized, and where the largest number of its members were living at the time of their enlistment, May 21, 1861. These two comrades are Hon. J. A: Fitchpatrick, of Nevada, and Jesse Bowen, of Maxwell, Iowa. The survivors of the regiment have held many reunions since the close of the war, all of which it has been my privilege to attend. They are now so few in number, so widely scattered, and so advanced in years, that they have probably met together in reunion for the last time. To some of the old comrades, who may chance to read this article, it may seem invidious to have mentioned so few of the names and deeds of those of the old regiment who fought at Blue Mills and Shiloh. To have done so, however, would have required the extension of this article to such length as to have occupied as much space as is devoted to an entire number of the Annals. I may, therefore, be pardoned for briefly calling attention to that exhaustive work, entitled: "Roster and Record of Iowa Soldiers," which can be found in all public libraries of the State, and which contains the personal record of each officer and enlisted man, as well as a brief historical sketch of every Iowa military organization. While it is true that those records are very brief-giving but a mere outline of the service performed-they have the merit of having been transcribed from the official records, and are therefore as full, complete and im- 
partial as was possible to make them. Except for their brevity, and whatever errors may have been made in the official reports and returns from which they were compiled, they may be regarded as substantially correct; while the incidents I have here mentioned, and the names connected with them, will be found-by comparison-to accord with the records contained in the work to which I have referred.

\section{A PLAINS ADVENTURE OF AN IOWA MAN.}

BY MARCELLUS PUGSLEY.

In the fall of 1862, John Henry, with his family, moved from Albert Lea, Minn., to Harrison county, Iowa. He brought a herd of cows and young cattle and during the fall he cut on the surrounding prairies enough hay to winter his stock, two hundred tons or more. The following winter he occupied an abandoned house one and one-half miles from my father's home.

During the winter we became acquainted and attended several debates at the country schoolhouses, and as the war for the Union was in full swing, the questions were generally political. He and I being Republicans stood for the flag in every case. Having a gift of strong language he did not spare the enemy.

About this time it became known that the great plains afforded almost unlimited pasturage both winter and summer. Mr. Henry decided to move to Colorado in the spring, and asked me to go with him at twenty dollars per month. I readily obtained the consent of my parents. I now know they were afraid I would go into the army as soon as I attained my majority, which would have been in a few months.

In April, Hotchkiss \& Wright, from Colorado, bought a herd of over one hundred cows and young cattle. It was agreed that we should go together. Our own herd consisted of one hundred and seventy, counting calves. L. Crane and 
Copyright of Annals of Iowa is the property of State of Iowa, by \& through the State Historical Society of Iowa and its content may not be copied or emailed to multiple sites or posted to a listserv without the copyright holder's express written permission. However, users may print, download, or email articles for individual use. 